\title{
Turbulent flux observations and modelling over a shallow lake and a wet grassland in the Nam Co basin, Tibetan Plateau
}

\author{
Tobias Biermann • Wolfgang Babel • Weiqiang Ma • \\ Xuelong Chen • Elisabeth Thiem • Yaoming Ma • \\ Thomas Foken
}

Received: 7 March 2013 / Accepted: 11 June 2013 / Published online: 5 July 2013

(C) The Author(s) 2013. This article is published with open access at Springerlink.com

\begin{abstract}
The Tibetan Plateau plays an important role in the global water cycle and is strongly influenced by climate change. While energy and matter fluxes have been more intensely studied over land surfaces, a large proportion of lakes have either been neglected or parameterised with simple bulk approaches. Therefore, turbulent fluxes were measured over wet grassland and a shallow lake with a single eddy-covariance complex at the shoreline in the Nam Co basin in summer 2009. Footprint analysis was used to split observations according to the underlying surface, and two sophisticated surface models were utilised to derive gap-free time series. Results were then compared with observations and simulations from a nearby eddy-covariance station over dry grassland, yielding pronounced differences. Observations and footprint integrated simulations compared
\end{abstract}

T. Biermann $(\bowtie) \cdot$ W. Babel $\cdot$ T. Foken

Department of Micrometeorology, University of Bayreuth, Universitätsstr. 30, 95440 Bayreuth, Germany

e-mail: tobias.biermann@uni-bayreuth.de

W. Ma

Cold and Arid Regions Environment and Engineering Research Institute, Chinese Academy of Sciences, Lanzhou, China

X. Chen

Faculty of Geo-Information Science and Earth Observation, University of Twente, Enschede, The Netherlands

E. Thiem

Department of Geography, Ludwig-Maximilian University, Munich, Germany

Y. Ma

Laboratory of Tibetan Environment Changes and Land Surface Processes, Institute of Tibetan Plateau Research, Chinese Academy of Sciences, Beijing, China

T. Foken

Member of Bayreuth Center of Ecology and Ecosystem Research (BayCEER), Bayreuth, Germany well, even for situations with flux contributions including grassland and lake. The accessibility problem for EC measurements on lakes can be overcome by combining standard meteorological measurements at the shoreline with model simulations, only requiring representative estimates of lake surface temperature.

\section{Introduction}

The role of the Tibetan Plateau in the global water cycle and its reaction to climate change has become a topic of strong scientific interest (e.g. Immerzeel et al. 2010; Ni 2011). Representing a unique geological formation, the Tibetan Plateau is considered the largest and highest plateau on earth, with an average elevation greater than $4,000 \mathrm{~m}$ a.s.1. Furthermore, the Tibetan Plateau is the source of a large number of major rivers in Asia. Its role in the modulation of the Asian Monsoon and the climate for large parts of Asia, because of its heat budget caused by its elevation in conjunction with the bordering Himalayan mountain range, has been of major research interest (Molnar et al. 2010; Boos and Kuang 2010).

To understand the role of the Tibetan Plateau for the global heat and water budget, much effort has been put into the estimation of energy balance and turbulent flux measurements within international campaigns like GAME/Tibet (Global Energy and Water cycle Experiment Asian Monsoon Experiment) and CAME (Coordinated Enhanced Observing Period Asia-Australia Monsoon Project) (Xu and Haginoya 2001; Ma et al. 2003; Ma et al. 2005) and in the framework of the Tibetan Observation and Research Platform (Ma et al. 2009).

Despite these efforts, observations on the Tibetan Plateau are sparse because of its remote location (Frauenfeld et al. 2005; Kang et al. 2010; Maussion et al. 2011). The importance of evaporation for the hydrological cycle under the 
influence of climate change has been highlighted by Yang et al. (2011).

Most long-term observation stations focus on the major land cover types such as alpine steppe, Kobresia pastures and wetlands (Zhao et al. 2010), however approximately $45,000 \mathrm{~km}^{2}$ of the plateau are covered by lakes (Xu et al. 2009). This lake area has been subject to changes in the last decades; the reasons are not well understood due to lack of observational data (Xu et al. 2009). Although Huang et al. (2008) report a general decrease of lake volume in QinghaiTibet Plateau, the Nam Co lake area has been increasing (Liu et al. 2010; Wu and Zhu 2008; Zhu et al. 2010). They attribute this change to increasing precipitation as well as thawing permafrost and glacial melt due to rising mean annual temperatures, nevertheless the relative contribution of the balance components, especially the role of evaporation, is discussed controversially. Consequently, fluxes over lake surfaces on the Tibetan Plateau should not be neglected since various studies have shown the contribution of lakes to the regional energy balance and water cycle in different catchments around the world (Rouse et al. 2005; Nordbo et al. 2011). Until now, estimations of evaporation over lake surfaces on the Tibetan Plateau have been modelled using remote sensing or land surface observations as forcing (Xu et al. 2009; Haginoya et al. 2009), whereas no direct measurements of turbulent fluxes over a lake surface have been conducted so far. The installation of a flux station in a lake on the Tibetan Plateau is nearly impossible, due to problems of accessibility, strong winds and waves during the summer, as well as ice cover during winter.

Nevertheless, it is known from model estimations that evaporation over lake surfaces differs from evapotranspiration over land throughout the year due to the heat storage capacity of the lakes and has a strong effect on convection and thus on local climates (Haginoya et al. 2009). The landscape on the Tibetan Plateau is fairly heterogeneous, including alpine steppe, Kobresia pygmea mats, wetlands and open water surfaces in various sizes. Therefore high quality evaporation measurements over water surfaces on the Tibetan Plateau need to be considered when data based on satellites or estimated with models is validated with ground-based flux measurements. Lakes differ strongly in their temperature regimes and exchange coefficients due to extent and depth (Rouse et al. 2005; Panin et al. 2006a; Nordbo et al. 2011). Evaporation estimation with simple bulk approaches on daily or monthly timescales (Haginoya et al. 2009; Xu et al. 2009; Krause et al. 2010; Yu et al. 2011) are not appropriate for resolving such differences. These specific characteristics of each lake, such as a diurnal course of atmospheric stratification over the lake surface, can only be captured by eddy measurements and more sophisticated models.

For this study, we selected the area around Nam Co, the largest and deepest lake in the Tibet Autonomous Region
(Xu et al. 2009; Liu et al. 2010). The Nam Co basin is considered one of the key areas of interest on the Tibetan Plateau due to its location influenced by the Westerlies, the South West Asian Monsoon and the East Asian Monsoon (Haginoya et al. 2009; Keil et al. 2010).

In order to measure fluxes over lake and land surfaces, we set up an eddy-covariance station at the shoreline of a shallow lake next to Nam Co.

Measured fluxes were utilised to validate simulations of two different surface models in order to estimate turbulent fluxes over the lake and adjacent grassland surface. For the lake surface, a validated hydrodynamic multilayer model (HM; Foken 1979, 1984) with an extension for shallow lakes (Panin and Foken 2005) and for the land surface, a SVAT model (SEWAB; Mengelkamp et al. 1999, 2001) were used to generate a complete time series for each surface. The simulated data set was then used to characterise the exchange for these surfaces and to link the simulations with spatial heterogeneity on footprint scale.

\section{Material and methods}

\subsection{Site description and setup of the EC stations}

The experiment was carried out during the 2009 summer monsoon season. The observation site was located in the Nam Co Basin, $220 \mathrm{~km}$ north of Lhasa, at 4,730 m a.s.l. on the Tibetan Plateau. The basin is dominated by Nam Co Lake and the Nyainqentanglha mountain range which stretches along the lake's SE side at approximately $5-10 \mathrm{~km}$ distance and reaches up to $7270 \mathrm{~m}$ a.s.l. with an average height of $5230 \mathrm{~m}$ (Liu et al. 2010). In the year 2000 the great lake had an area of $1,980 \mathrm{~km}^{2}$ (Wu and Zhu 2008).

Atmospheric fluxes were observed with two eddycovariance and energy balance stations. One station was set up by the University of Bayreuth (NamUBT) at a shallow lake of approximately $1 \mathrm{~km}^{2}$ in area located at the SE side of Nam Co Lake. It was installed adjacent to the southern shoreline of the lake to ensure that measurements from the lake and land surface were identifiable according to the instantaneous wind direction. The other station at roughly $300 \mathrm{~m}$ distance is the permanently operating eddycovariance complex (NamITP) within the Nam Co Monitoring and Research Station for Multisphere Interactions, NAMORS $\left(30^{\circ} 46^{\prime} 22^{\prime \prime} \mathrm{N}, 90^{\circ} 57^{\prime} 47^{\prime \prime} \mathrm{E}\right)$ operated by the Institute of Tibetan Plateau Research (ITP), Chinese Academy of Sciences (CAS) (Ma et al. 2009). A detailed map of the field site and pictures of the two stations can be seen in Fig. 1.

The soil is moister at NamUBT than at NamITP due to the influence of the water table around the small lake. To account for the effect of higher moisture supply on the vegetation, we 


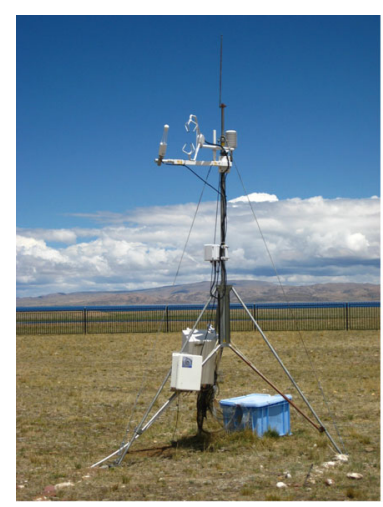

NamITP

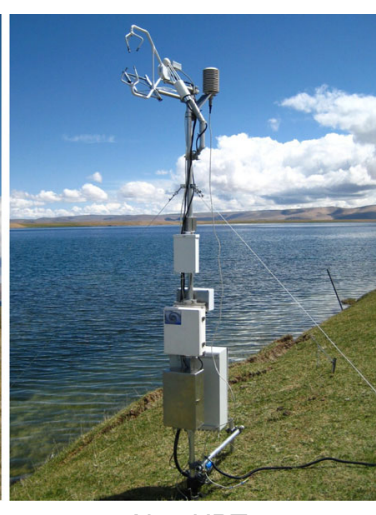

NamUBT

Fig. 1 Measurement site in Nam Co Basin, showing the small lake, the land use, the EC Stations NamITP (left) and NamUBT (right). NamITP is marked with a red cross and NamUBT with a black error mark. Land use is classified as wetland (dark green), moist (positive, medium green)

have classified the grassland into grass ${ }^{+}$for denser and moister vegetation and grass ${ }^{-}$for comparatively drier and sparser vegetation. From NamUBT the terrain rises gently in three terraces to the level of NamITP, with an average slope of approximately $8^{\circ}$. The shoreline of the small lake in the vicinity of NamUBT is fairly steep, with the lake starting out quite shallow and reaching a maximum depth of $12 \mathrm{~m}$ at the centre. Soils and vegetation around both stations are typical for a semi-arid to semi-humid climate at this altitude. Soil types range from alpine steppe to desert soils and the vegetation is dominated by alpine meadow and steppe grasses including species of Stipa, Carex, Kobresia and Oxytropis (Mügler et al. 2010).

Both eddy-covariance stations were equipped with an ultrasonic anemometer and an infrared gas analyser. Standard meteorological measurements are available for both stations and, additionally, all necessary components for the estimation of the energy balance were measured.

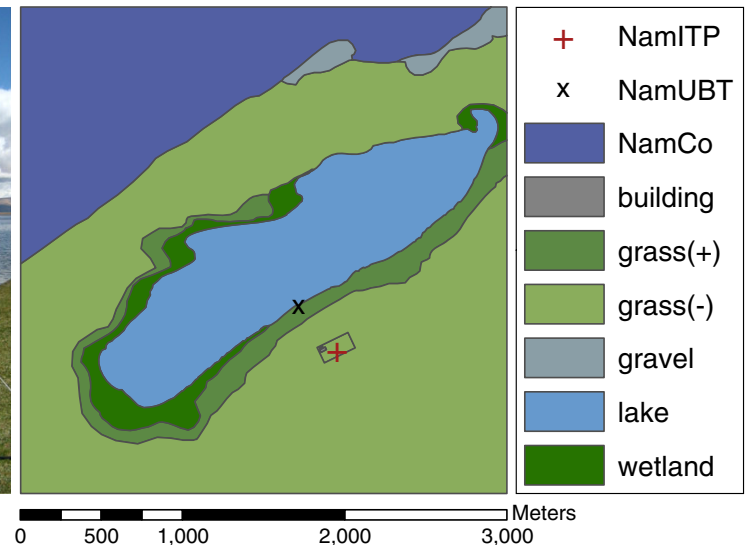

and dry (negative, light green) grassland; the small lake (light blue); and Nam Co (dark blue). In addition, at the shore line of Nam Co, partly flooded gravel bars are shown in light grey. The Nam Co Station buildings are marked in dark grey (Illustration from Gerken et al. 2012)

For specifications of the two stations, see Table 1 or Biermann et al. (2009) for NamUBT, and Zhou et al. (2011) for NamITP.

\subsection{Analysis of observed data}

\subsubsection{EC data processing}

The measurements of both eddy-covariance stations were post-processed using the TK2/3 software package, developed at the Department of Micrometeorology, University of Bayreuth (Mauder and Foken 2004, 2011) and evaluated in an international comparison study by Mauder et al. (2008). The software applies all necessary flux corrections and postprocessing steps for turbulence measurements as recommended in Foken et al. (2012) and Rebmann et al. (2012).

Further data processing included quality filtering according to Foken and Wichura (1996), using the quality

Table 1 Specifications of the eddy-covariance stations NamUBT and NamITP

\begin{tabular}{|c|c|c|c|}
\hline & Instrument & NamUBT & NamITP \\
\hline Surface & & Lake, grass ${ }^{+}$and grass ${ }^{-}$ & Grass $^{-}$ \\
\hline Ultrasonic anemometer & CSAT3 (Campbell Scientific Ltd.) & $3.0 \mathrm{~m}$ & $3.1 \mathrm{~m}$ \\
\hline Gas analyser & LI-COR7500 (LI-COR Biosciences) & $2.9 \mathrm{~m}$ & $3.1 \mathrm{~m}$ \\
\hline Temperature-humidity sensor & HMP 45 (Vaisalla) & $3.0 \mathrm{~m}$ & $3.1 \mathrm{~m}$ \\
\hline Net radiometer & CNR1 (Kipp \& Zonen) & $2.0 \mathrm{~m}$ & - \\
\hline Net radiometer & CM3 and CG3 (Kipp \& Zonen) & - & $1.5 \mathrm{~m}$ \\
\hline Rain gauge & Tipping bucket & $1 \mathrm{~m}$ & $1 \mathrm{~m}$ \\
\hline Soil moisture & Imko-TDR & $-0.1,-0.3$ and -0.5 & $-0.1,-0.2,-0.4,-0.8$ and -1.60 \\
\hline Soil temperature & Pt100 & $\begin{array}{l}-0.025,-0.05,-0.1,-0.15 \\
\quad-0.2,-0.3 \text { and }-0.5\end{array}$ & $-0.2,-0.4,-0.8$ and -1.60 \\
\hline Soil heat flux & HP3 & -0.15 & - \\
\hline Water temperature & Pt100 & -0.3 & - \\
\hline Logger & (Campbell Scientific Ltd.) & CR3000 & CR5000 \\
\hline
\end{tabular}


flagging scheme as recommended by Foken et al. (2004). For displaying diurnal cycles, we used best to intermediate quality flagged data (Flag 1-6 out of 9 classes) and for model performance evaluation, we used best quality flagged data (Flag 1-3).

\subsubsection{Coordinate rotation and footprint analysis}

In this section, we describe the coordinate rotation and footprint analysis which was conducted for both EC stations. We focus mainly on the analysis for NamUBT, since for NamITP detailed studies of footprint and data quality can be found for other data sets in Zhou et al. (2011) and Metzger et al. (2006).

The wind direction exhibits a strong diurnal pattern due to a land - lake circulation system, which can be seen in NamUBT data (Fig. 2).

During midday, the wind came predominantly from the direction of the lake while in the morning, evening and nighttime hours wind from the land surface dominated. Therefore NamUBT provides flux measurements over the land and water surface only for certain periods of the day, while NamITP always represents fluxes from the land surface.

For the necessary coordinate rotation, we chose the planar-fit method according to Wilczak et al. (2001) which rotates the coordinate system into the mean streamlines by fitting a plane to individual half-hourly mean wind velocity components. While the mean vertical wind for the whole period is set to zero by this method, the individual halfhourly values do not vanish completely. Eddy-covariance measurements require a homogeneous flow field as a prerequisite. In our study this is not the case at NamUBT due to the transition from the plane lake surface to the gently sloping grassland. Paw et al. (2000) and Finnigan et al. (2003) suggest considering such terrain structures in the rotation procedure of the eddy-covariance data. Therefore the planar-fit rotation was applied for four different sectors according to Fig. 2. This procedure accounts for two planes with different slopes and two transition areas. Most of the vertical wind speed disappears after the rotation; $95 \%$ of the vertical wind speed data for the lake and for the land surface remain within \pm 0.1 and $\pm 0.07 \mathrm{~ms}^{-1}$, respectively. For wind sectors parallel to the shoreline, $95 \%$ of the residual mean vertical wind velocity stays within $\pm 0.12 \mathrm{~ms}^{-1}$. These values stay within acceptable limits, compared to a multi-site quality analysis by Göckede et al. (2008).

The footprint analysis was conducted following Göckede et al. (2004, 2008). The approach is based on a Lagrangian stochastic forward model providing two dimensional contributions of source areas (Rannik et al. 2000). The resulting footprint for NamUBT (Fig. 3) shows that flux contributions from the lake are not found under stable conditions, which are typical for night times, while they can be found during unstable and neutral stratification. These findings match well with the distribution of wind directions mentioned above.

The footprint analysis includes not only the calculation of the footprint, but also the spatial distribution of flux quality according to Göckede et al. (2008), which enables the user to identify spatial patterns such as obstacles or heterogeneities contributing to the quality of the measured fluxes. In our study no such patterns could be identified for either station.

The average land use contribution to the measured signal for unstable and neutral stratification depending on the wind direction is shown in Fig. 4. The differentiation between stability classes were defined by the stability parameter $z$ $L^{-1}$ with the measurement height $z$ and $L$ as the Obukhov length. The contribution from grass ${ }^{+}$dominates the influence of the land surface in the respective wind sector. Influence of wetland and buildings are close to zero, even for stable conditions (not shown). The influence of grass ${ }^{-}$is comparatively small. During stable conditions, it is larger but these occur mostly at night, when flux differences between grass ${ }^{-}$ and grass ${ }^{+}$are negligible. Therefore, it is reasonable to relate land surface parameters to the wetter grass ${ }^{+}$surface and we continue with a simplified land use scheme, discriminating only between land $\left(\right.$ grass $^{+}$) and lake for NamUBT. The footprint analysis of NamITP confirmed the representativeness of this station for grass ${ }^{-}$.

\subsubsection{Energy balance correction}

Investigation of the energy balance closure (Foken 2008) at NamUBT shows that $70 \%$ of the energy balance is closed for the measurement period, a typical value for flux stations in heterogeneous landscapes. The energy balance closure correction (EBC) for the land surface fluxes was calculated after Twine et al. (2000), distributing the residual of the energy balance according to the Bowen ratio to the latent and
Fig. 2 Temporal distribution of the wind direction for the measuring period 27 June to 8 August and corresponding land use in upwind direction, classified according to the sectors shown on the right

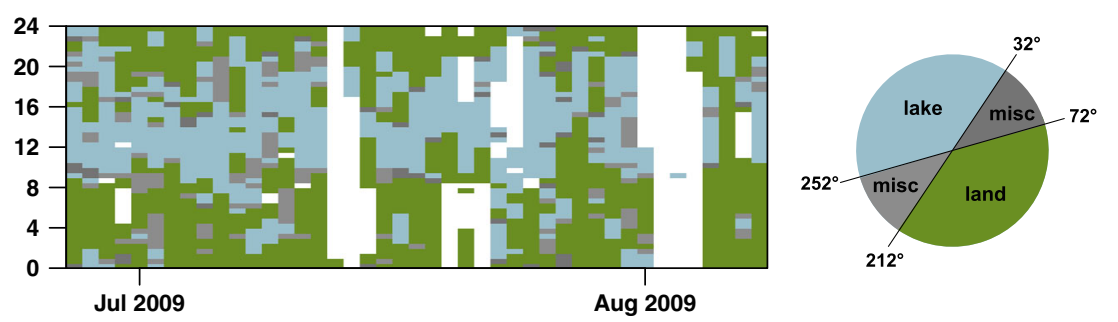


Fig. 3 Footprint climatology of NamUBT for the measuring period 27 June to 8 August. The figures show a combined footprint as well as footprints under unstable $\left(z L^{-1} \leq-0.0625\right)$, neutral $\left(-0.0625 \leq z L^{-1} \leq 0.0625\right)$ and stable stratification $\left(z L^{-1}>0.0625\right)$ of the atmosphere
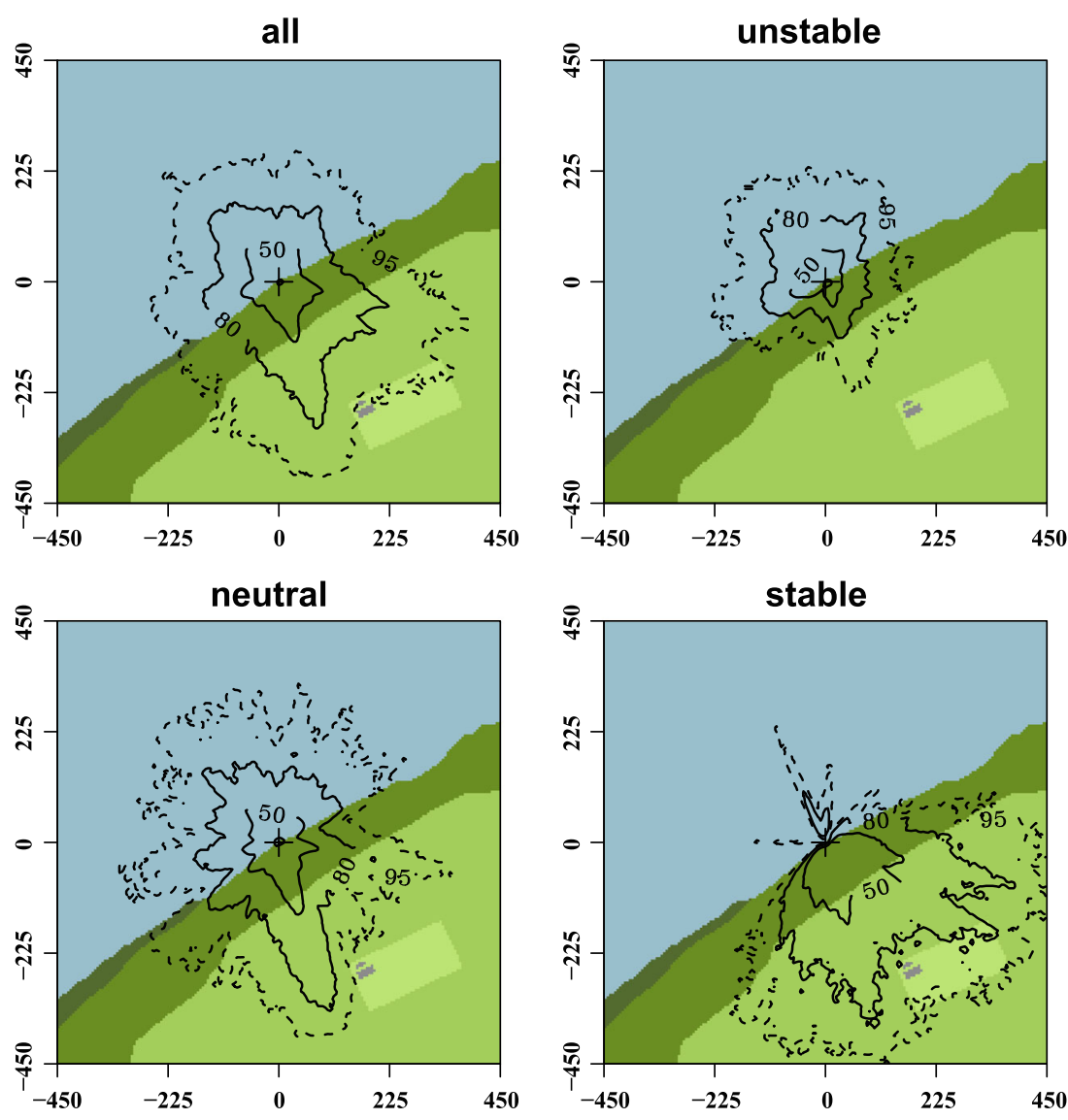

$\begin{array}{llll}\square \text { grass }^{-} & \square \text { wetland } & \square \text { grass }^{-} \text {, fenced } \\ \square \text { grass }^{+} & \square \text { lake } & \square \text { building }\end{array}$

sensible heat flux. We subsequently refer to this correction as EBC-Bo. Since Kracher et al. (2009) show with another data set that the land surface model SEWAB, which is used in this study (see Section 2.3.1), roughly preserves the Bowen ratio

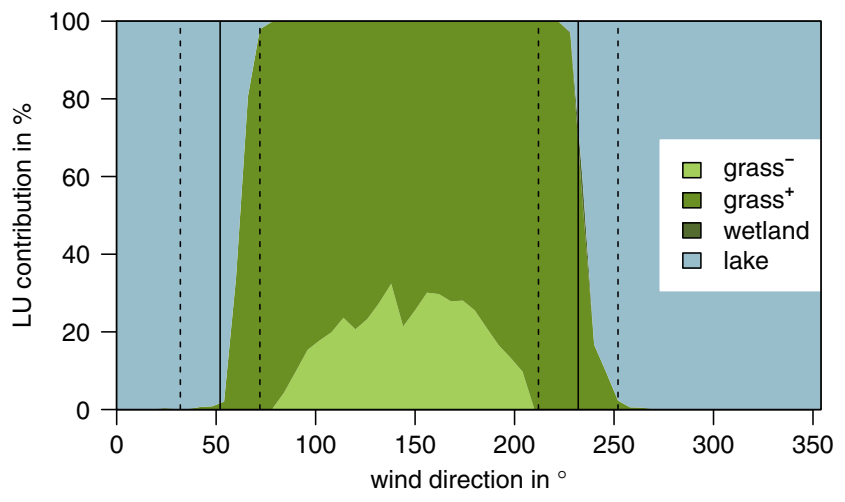

Fig. 4 Average land use contribution of NamUBT under unstable and neutral conditions $\left(z L^{-1} \leq 0.0625\right)$ for all wind directions. Solid lines represent the shoreline; dashed lines represent the borders of the sectors classified as land, lake and miscellaneous (misc) in Fig. 2 measured by eddy covariance, we regard EBC-Bo as a suitable correction for comparing the observations with SEWAB.

Nevertheless, recent studies suggest that a predominant fraction of the residual should be attributed to the sensible heat flux (Mauder and Foken 2006; Ingwersen et al. 2011; Foken et al. 2012). In case the reason for the unclosed energy balance is the existence of secondary circulations due to convection, as hypothesized by Foken et al. (2010, 2011), a physically meaningful correction would be related to buoyancy. The buoyancy flux $Q_{\mathrm{HB}}$ is driven by differences in air density and thus can be decomposed into a fraction governed by sensible heat (density differences because of temperature) and a fraction governed by latent heat (density differences due to moisture). The findings mentioned above suggest a correction where the residual of the energy balance is distributed to the sensible and latent heat flux according to their contribution to the buoyancy flux. This fraction depends on the Bowen ratio Bo and (to a small extent) on air temperature, and more than $90 \%$ are attributed to the sensible heat flux in the case of $\mathrm{Bo}=1$ and approximately $60 \%$ in the case 
of $\mathrm{Bo}=0.1$. We applied this correction, here named EBC$\mathrm{HB}$, for comparison with the more common EBC-Bo.

The EBC for the lake surface could not be estimated since only one sensor was used to measure the water temperature and no measurements of the storage flux within the lake or the sediment were conducted.

\subsection{Modelling of the turbulent fluxes}

Because of the location of NamUBT at the shore line, the wind direction determined whether turbulent fluxes over the land or the lake surface were measured, resulting in gaps of one or the other time series. Therefore, a model was applied for each surface type and validated with the existing data. The results then complete the flux time series for the land and lake surface.

In addition, fluxes for grass ${ }^{-}$at NamITP were modelled using the same land surface model.

\subsubsection{Description of the models used}

For the lake surface, a HM by Foken $(1979,1984)$ was utilised. In order to account for multiple layers within the surface layer, turbulent fluxes are parameterised in HM using an integrated profile coefficient. As opposed to a single bulk coefficient, the integrated profile coefficient resolves the molecular boundary layer, the viscous buffer layer and the turbulent layer. Therefore, near-surface exchange conditions are reflected according to hydrodynamic theory. Originally designed for exchange over the ocean, a correction term for shallow water (Panin and Foken 2005) was added, resulting in increased turbulent fluxes due to an enhanced mixing by higher waves in shallow water. The model has been successfully applied to simulate fluxes above ocean surfaces and lakes with a large fetch as well as over arctic snow fields (Panin et al. 2006b; Foken 1986; Lüers and Bareiss 2010). Details of the governing equations can be found in Table 2 .

Turbulent fluxes over the land surface were simulated with the one-dimensional SEWAB scheme (Mengelkamp et al. 1999, 2001), a soil-vegetation-atmosphere-transfer model. All energy balance components are given separately. Turbulent fluxes are formulated with bulk approaches, atmospheric stability is considered. The main features are summarized in Table 3. The energy balance is then closed by iteration of the surface temperature. Evapotranspiration from vegetation is calculated with a single leaf concept in a Jarvis-type scheme after Noilhan and Planton (1989). Emphasis is placed on the description of soil processes. Soil temperature distribution and vertical soil water movement are described by the diffusion equation and the Richards equation, respectively. Soil moisture characteristics are inter-related following Clapp and Hornberger (1978).

Both models were forced with standard meteorological insitu measurements. In order to provide gap-free input data,

Table 2 Governing equations for the HM (Foken 1979, 1984) with shallow water extension (Panin and Foken 2005)

\begin{tabular}{|c|c|}
\hline Variable/component & Equation \\
\hline Sensible heat flux & $Q_{\mathrm{H}}^{\text {ocean }}=\Gamma\left(T_{\mathrm{sfc}}-T_{z}\right)$ with $\Gamma=\kappa \cdot u_{*} \cdot\left[\left(\kappa \cdot \operatorname{Pr}-\frac{1}{6}\right) \cdot \delta_{\mathrm{T}}^{+}+5+\ln \frac{u_{*} \cdot z}{30 \nu}\right]^{-1}$ \\
\hline Latent heat flux & Analog to $Q_{\mathrm{H}}{ }^{\text {ocean }}$, assuming $\delta_{\mathrm{T}}^{+} \approx \delta_{\mathrm{q}}^{+}, \Delta T^{+} \approx \Delta q^{+}$and replacing Pr with Sc \\
\hline Stability dependence & $\begin{array}{l}\text { Monin-Obukhov Similarity Theory, universal function after Foken and } \\
\text { Skeib (1983) }\end{array}$ \\
\hline Shallow water term & $\begin{array}{l}Q_{\mathrm{H}, \mathrm{E}}^{\mathrm{SW}}=Q_{\mathrm{H}, \mathrm{E}}{ }^{\text {ocean }} \cdot\left(1+k_{\mathrm{H}, \mathrm{E}}{ }^{\mathrm{SW}} \cdot h H^{-1}\right) \text { with mean square wave height } \\
\quad h \approx 0.07 u_{z}^{2}\left(g H \cdot\left(u_{z}{ }^{-2}\right)\right)^{0.6} \cdot g^{-1} \text { (Davidan et al. 1985) and } k_{\mathrm{H}, \mathrm{E}} \mathrm{SW}_{\approx 2} \\
\quad(\text { Panin et al. 2006b) }\end{array}$ \\
\hline
\end{tabular}

Symbols

$g$ gravity acceleration $\left(\mathrm{ms}^{-2}\right)$

$T$ temperature $(\mathrm{K})$

$H$ lake depth (m)

$T^{+}$dimensionless temperature (-)

$h$ mean square wave height $(\mathrm{m})$

$k_{\mathrm{H}, \mathrm{E}} \mathrm{SW}$ empirical correction factor (-)

Pr Prandtl number (-)

$Q_{\mathrm{H}, \mathrm{E}}{ }^{\text {ocean }}$ sensible $(H)$ and latent $(L)$ heat flux without shallow water correction $\left(\mathrm{W} \mathrm{m}^{-2}\right)$

$Q_{\mathrm{H}, \mathrm{E}}{ }^{\mathrm{SW}}$ sensible (H) and latent (L) heat flux with shallow water correction (W m ${ }^{-2}$ )

$q$ specific humidity (-)

Sc Schmid number (-)

$u *$ friction velocity $\left(\mathrm{ms}^{-1}\right)$

$u_{z}$ wind velocity in height $\mathrm{z}\left(\mathrm{ms}^{-1}\right)$

$z$ measurement height $(\mathrm{m})$

$\Gamma$ profile coefficient $\left(\mathrm{ms}^{-1}\right)$

$\delta_{\mathrm{T}}{ }^{+}$dimensionless thickness of the molecular temperature boundary layer (-)

$\kappa$ von Kármán constant $(-)$

$\nu$ kinematic viscosity $\left(\mathrm{m}^{2} \mathrm{~s}^{-1}\right)$ 
Table 3 Governing equations for SEWAB (Mengelkamp et al. 1999, 2001) and adaptations to the Tibetan Plateau as used in Babel et al. (2013)

\begin{tabular}{|c|c|}
\hline Variable/component & Equation \\
\hline Net radiation & $R_{\mathrm{net}}=-R_{\mathrm{swd}}(1-a)-R_{\mathrm{lwd}}+\varepsilon \sigma T_{\mathrm{sfc}}{ }^{4} R_{\mathrm{swd}}$ and $R_{\mathrm{lwd}}$ in forcing data set \\
\hline Ground heat flux & $Q_{\mathrm{G}}=\lambda_{\mathrm{s}}\left(T_{\mathrm{sfc}}-T_{S 1}\right) \cdot \Delta z_{S 1}{ }^{-1}$ \\
\hline Sensible heat flux & $\mathrm{Q}_{\mathrm{H}}=C_{\mathrm{H}} \rho c_{\mathrm{p}} u(z)\left(T_{\mathrm{sfc}}-T(z)\right)$ \\
\hline Latent heat flux & $\begin{array}{l}\text { Composed of bare soil } E_{s} \text {, wet foliage } E_{f} \text { and plant transpiration } E_{t r} \text { afte } \\
\qquad \begin{array}{l}E_{\mathrm{s}}=C_{\mathrm{E}} \rho u(z)\left(\alpha q_{\mathrm{s}}\left(T_{\mathrm{sfc}}\right)-q(z)\right) \\
E_{\mathrm{f}}=C_{\mathrm{E}} \rho u(z)\left(q_{\mathrm{s}}\left(T_{\mathrm{sfc}}\right)-q(z)\right) \\
E_{\mathrm{tr}}=\left(R_{\mathrm{a}}-R_{\mathrm{s}}\right)^{-1} \rho\left(q_{\mathrm{s}}\left(T_{\mathrm{sfc}}\right)-q(z)\right)\end{array}\end{array}$ \\
\hline Stability dependence & $C_{\mathrm{H}}$ after Louis (1979), $C_{\mathrm{E}}=C_{\mathrm{H}}$ \\
\hline \multicolumn{2}{|l|}{ Adaptations to TP } \\
\hline $\begin{array}{l}\text { Soil thermal conductivity } \\
\text { Thermal roughness length }\end{array}$ & $\begin{array}{l}\lambda_{s}(\Theta)=\lambda_{\text {dry }}+\left(\lambda_{\text {sat }}-\lambda_{\text {dry }}\right) \exp \left[k_{T}\left(1-\Theta_{\text {sat }} / \Theta\right)\right], k_{\mathrm{T}}=0.36 \text { (Yang et al. 2005) } \\
z_{0 \mathrm{~h}}=70 \nu \cdot u_{*}{ }^{-1} \cdot \exp \left(-\beta u_{*}{ }^{0.5}\left|T_{*}\right|^{0.25}\right) \\
\beta=7.2 \mathrm{~s}^{0.5} \mathrm{~m}^{-0.5} \mathrm{~K}^{-0.25} \text { (Yang et al. 2008) }\end{array}$ \\
\hline Bare soil evaporation & 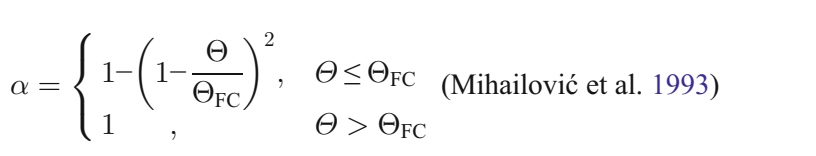 \\
\hline \multicolumn{2}{|l|}{ Symbols } \\
\hline$a$ albedo (-) & $\alpha$ dependence factor of soil air humidity to soil water content (-) \\
\hline$C_{H}$ Stanton number $(-)$ & $\varepsilon$ emissivity $(-)$ \\
\hline$C_{E}$ Dalton number $(-)$ & $\Theta$ volumetric soil water content $(-)$ \\
\hline$c_{p}$ air heat capacity $\left(\mathrm{J} \mathrm{kg}^{-1} \mathrm{~K}^{-1}\right)$ & $\Theta_{\text {sat }}$ volumetric soil water content at saturation, porosity $(-)$ \\
\hline$q$ specific humidity $(-)$ & $\Theta_{\mathrm{FC}}$ volumetric soil water content at field capacity $(-)$ \\
\hline$q_{s}$ saturation specific humidity $(-)$ & $\lambda_{\mathrm{s}}$ soil thermal conductivity $\left(\mathrm{W} \mathrm{m}^{-1} \mathrm{~K}^{-1}\right.$ ) \\
\hline$R_{a}$ turbulent atmospheric resistance $\left(\mathrm{s} \mathrm{m}^{-1}\right)$ & $\lambda_{\text {dry }}$ soil thermal conductivity for dry soil $\left(\mathrm{W} \mathrm{m}^{-1} \mathrm{~K}^{-1}\right)$ \\
\hline$R_{S}$ stomata resistance $\left(\mathrm{s} \mathrm{m}^{-1}\right)$ & $\lambda_{\text {sat }}$ soil thermal conductivity, soil moisture at saturation $\left(\mathrm{W} \mathrm{m}^{-1} \mathrm{~K}^{-1}\right)$ \\
\hline$R_{\text {lwd }}$ long-wave downward radiation $\left(\mathrm{W} \mathrm{m}^{-2}\right)$ & $\rho$ air density $\left(\mathrm{kg} \mathrm{m}^{-3}\right)$ \\
\hline$R_{\text {swd }}$ short-wave downward radiation $\left(\mathrm{W} \mathrm{m}^{-2}\right)$ & $\sigma$ Stefan Boltzmann constant $\left(\mathrm{W} \mathrm{m}^{-2} \mathrm{~K}^{-4}\right)$ \\
\hline$T$ temperature $(\mathrm{K})$ & $\nu$ kinematic viscosity $\left(\mathrm{m}^{2} \mathrm{~s}^{-1}\right)$ \\
\hline \multicolumn{2}{|l|}{$T_{*}$ dynamic temperature scale $(\mathrm{K})$} \\
\hline \multicolumn{2}{|l|}{$T_{\text {sfc }}$ surface temperature $(\mathrm{K})$} \\
\hline \multicolumn{2}{|l|}{$T_{S 1}$ temperature in first soil layer $(\mathrm{K})$} \\
\hline \multicolumn{2}{|l|}{$u_{*}$ friction velocity $\left(\mathrm{ms}^{-1}\right)$} \\
\hline$\Delta z_{S 1}$ thickness of first soil layer (m) & \\
\hline
\end{tabular}

the small gaps within the forcing data from NamUBT were filled by linear interpolation while larger gaps were filled by linear regression using the data from NAMORS.

\subsubsection{Application of the HM model to a shallow lake}

The forcing data set for the HM model includes the standard meteorological parameters wind velocity, air temperature, humidity and air pressure. Radiation measurements are not required for the HM model, instead water surface temperature has to be supplied instead. In this study we used the measured water temperature (Table 1) as an estimate for the water surface temperature.

Wendisch and Foken (1989) investigated the relative error contribution of model parameter, amongst others water temperature, air temperature, air humidity and wind velocity, to 
the model output with a sensitivity analysis (Fourier Amplitude Sensitivity Test by Cukier et al. 1978). Assuming typical measurement errors for the initial parameter distribution they estimated that water temperature contributed up to $50 \%$ of the overall error while the influence of wind velocity, air temperature and humidity are comparatively small, each contributing $10-20 \%$ to the error. Since the temperature probe was only shielded against direct (downward) radiation, the effect of diffuse radiation on the accuracy of the water temperature measurements was evaluated. The radiation error has been estimated with a graphical analysis of short term temperature perturbations as related to rapid changes in downward shortwave radiation. Caused by the small fraction of diffuse radiation in the low air density of the Tibetan Plateau and sudden cloud cover changes, the shortwave radiation observations occasionally drop from 1,000 to $150 \mathrm{~W} \mathrm{~m}^{-2}$ (or increase in reverse) within a few minutes. The corresponding shifts in water temperature suggest a possible radiation error of approximately $0.2 \mathrm{~K}$. Therefore, water temperature measurements have been accepted for model forcing without correction.

The shallow water parameterisation included in the current version of the HM model accounts for an enhanced turbulent exchange due to increased wave heights in shallow water. Consequently, the turbulent fluxes increase with the mean square wave height (Table 2). Together with the wave height parameterisation after Davidan et al. (1985), additional parameters influence the model results. These are the wind velocity, lake depth and an empirical coefficient, which was set to 2 in this study following Panin et al. (2006b). In this study, the water depth has been estimated as $1.5 \mathrm{~m}$ within the average footprint area of the measurement period.

The influence of the shallow water term becomes dominant with increasing wind velocity and decreasing water depth. Calculation of the shallow water equations described in Table 2 with the estimated water depth of $1.5 \mathrm{~m}$ and the average wind velocity of $4 \mathrm{~ms}^{-1}$ yields an increase in turbulent fluxes of $14.5 \%$ compared with deep water conditions. Consideration of small changes in wind velocity and water depth yields local sensitivities of roughly $2.9 \% / \mathrm{ms}^{-1}$ of the deep water fluxes $/ \mathrm{m}^{-1}$ and $-3.9 \% / \mathrm{m}^{-1}$ water depth, respectively. For high wind velocities $\left(10 \mathrm{~ms}^{-1}\right)$ the shallow water extension causes an increase of $30.1 \%$ with sensitivities of $2.4 \% / \mathrm{ms}^{-1}$ and $-8.0 \% / \mathrm{m}$ water depth. Assuming a typical error of $0.3 \mathrm{~ms}^{-1}$ for wind velocity and variability of the lake depth up to $1 \mathrm{~m}$ within the footprint leads to flux uncertainties of 1 and $4 \%$, respectively. These errors, although not negligible, are within the uncertainty range of the EC flux measurements.

\subsubsection{Adaptation of SEWAB}

On the Tibetan Plateau, a strong diurnal cycle of the surface temperature during dry periods over bare soil and short grassland have been observed, which typically leads to an overestimation of surface sensible heat flux (Yang et al. 2009; Hong and Kim 2010). To account for these conditions, SEWAB has been adapted for the Tibetan Plateau by (1) a revised calculation of the soil thermal conductivity as used in Yang et al. (2005), (2) a different formulation of the thermal roughness length after Yang et al. (2008) and (3) by changing the parameterisation of bare soil evaporation according to Mihailović et al. (1993). The formulations can be seen in Table 3.

These changes have been implemented using flux data from NamITP station and flux data from NamUBT corresponding to land surface (Babel et al. 2013), who evaluated this adaptation as an improvement compared with the original version.

SEWAB has been run offline, forced by measurements of precipitation, air temperature, wind velocity, air pressure, relative humidity and downwelling shortwave and longwave radiation. The respective parameters for both land surface types were estimated by a combination from the in-situ measurements and laboratory investigation of soil characteristics (Chen et al. 2012). Surface emissivity, leaf area index and minimum stomatal resistance have been derived from various sources (Yang et al. 2009; Hu et al. 2009; Alapaty et al. 1997)

\subsection{Statistics}

For evaluation of model performance, simple comparisons were carried out using the $\operatorname{bias} B=N^{-1} \sum_{i=1}^{\mathrm{N}}\left(P_{i}-O_{i}\right)$ and the mean absolute error MAE $=N^{-1} \sum_{i=1}^{\mathrm{N}}\left|P_{i}-O_{i}\right|$, with $O$ as the observations and $\mathrm{P}$ the model predictions.

In equivalence to the MAE, the differences between two time series of predictions can be quantified and we define the desired measure as

$\delta_{\text {sim }}=N^{-1} \sum_{i=1}^{\mathrm{N}}\left|P_{1, i}-P_{2, i}\right|$

with $P_{1}$ and $P_{2}$ as predictions from the respective land use types 1 and 2. The Nash-Sutcliffe coefficient (NS) serves as a goodness-of-fit measure

$\mathrm{NS}=1-\frac{\sum_{i=1}^{N}\left(P_{i}-O_{i}\right)^{2}}{\sum_{i=1}^{N}\left(O_{i}-\bar{O}\right)^{2}}$

with $\bar{O}$ as the mean of the observations. 


\section{Results}

\subsection{Flux measurements}

The measured energy fluxes over the lake surface and land $\left(\right.$ grass $^{+}$) show pronounced differences in their magnitude and dynamics. The daytime net radiation is substantially higher over the lake surface, caused by a lower albedo and decreased upwelling longwave radiation due to damped surface temperatures over the lake (Fig. 5c). However, upward radiation components were only measured over the land surface; for the lake surface they were parameterised using an albedo of 0.06 and the lake surface temperature with an emissivity of 0.96 .

As expected for the monsoon season on the Tibetan Plateau, the latent heat flux over the land surface was larger than the sensible heat flux (Fig. 5a, b). This observation is in agreement with, e.g. Gu et al. (2005) and Ma and Ma (2006). The mean diurnal cycles of surface and air temperature also show the typical dynamics above land surface, with unstable stratification during daytime but higher surface temperatures are observed over grass ${ }^{-}$. Ground heat flux and sensible heat flux are in the same order of magnitude for each land surface again with higher values for grass ${ }^{-}$. In consequence, the latent heat flux is lower over this land surface.

The turbulent fluxes over the lake, however, do not show a diurnal cycle, but remain constant over the day. The energy input from radiation is stored in the lake body and is available at any time as indicated by the lake surface temperature in Fig. 5c. No complete energy balance could be estimated over the lake surface, as no measurements exist for the heat storage in the water body and heat fluxes into the sediment.
Evaporation is comparably high for lake surfaces due to high wind velocities of $4 \mathrm{~ms}^{-1}$ on average. In addition, high lake surface temperatures, caused by the shallow water table and the small extent of this lake, lead to unstable stratification even during daytime (Fig. 5c). Therefore turbulent exchange is enhanced compared with stable stratification typically found over lake surfaces during daytime (e.g. Beyrich et al. 2006; Nordbo et al. 2011).

\subsection{Model performance}

Different measures for model performance are summarised in Table 4. The results from grass ${ }^{+}$simulations show reasonable performance, although there are only few observations left after filtering, separation and energy balance closure correction (Fig. 6). In case of the EBC-Bo-corrected observations, the latent heat flux is slightly underestimated while the simulation of the sensible heat flux resembles the measurements quite well. The opposite is true when using the buoyancy flux method for energy balance closure correction (EBC-HB). The correlation is affected in a similar way. Good $R^{2}$ values are achieved for the sensible heat flux corrected using EBC-Bo and latent heat flux corrected using EBC-HB, and they decrease for the other two cases. Lake surface modelling yields reasonable coherence to the EC observations within the footprint of the measurements, with a bias of -23.3 and $-2.7 \mathrm{~W} \mathrm{~m}^{-2}$ for the latent heat flux $Q_{\mathrm{E}}$ and the sensible heat flux $Q_{\mathrm{H}}$, respectively.

For grass ${ }^{-}$at NamITP, mean absolute errors for sensible heat flux are larger, mainly caused by the bias, although a good correlation is obtained in the case of EBC-Bo corrected observations. Aside from model deficiencies, the reason for
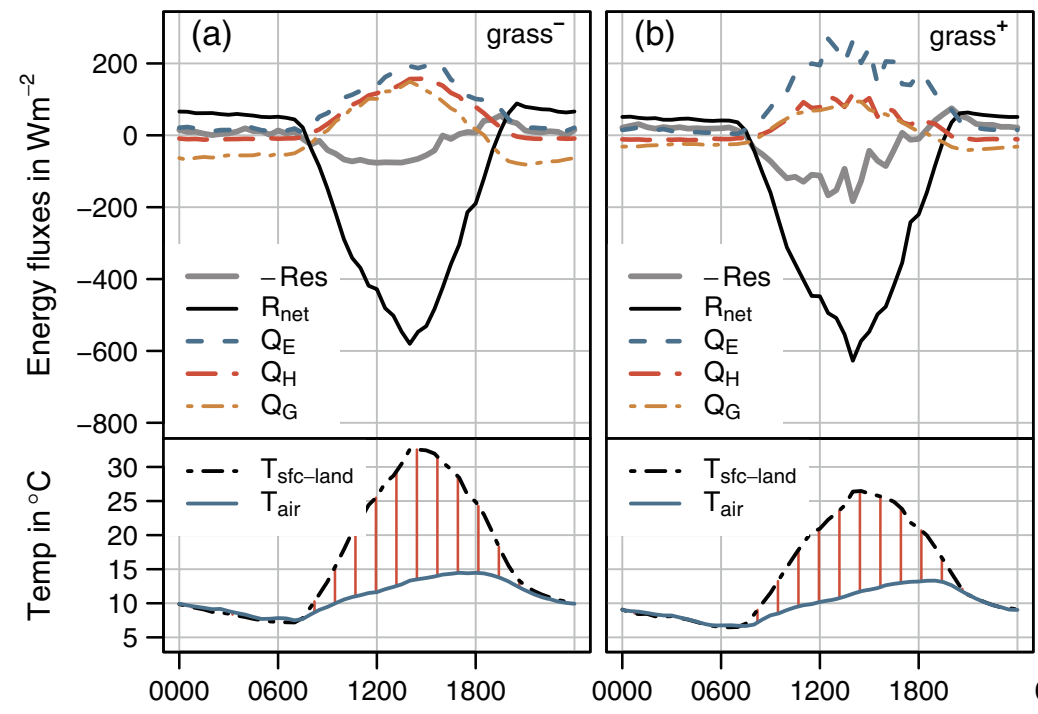

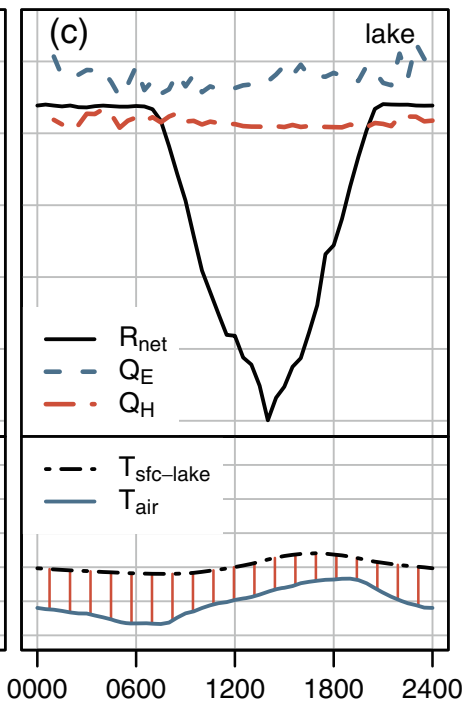

Fig. 5 Mean diurnal energy fluxes for the whole measurement period, separated for $\mathbf{a}$ grass $^{-}, \mathbf{b}$ grass $^{+}$and $\mathbf{c}$ lake; for land surfaces, all components are measured; lake fluxes, the net radiation is calculated from measured downwelling radiation and using an albedo of 0.06 and the lake surface temperature with an emissivity of 0.96 ; the lower panel shows diurnal surface and air temperature. The time axis is displayed in Beijing standard time (CST), mean local solar noon during the observation period is at $1400 \mathrm{CST}$ 
Table 4 Model performance of turbulent fluxes for the three land use types and two energy balance correction methods for the land observations: number of observations, bias, mean absolute error (MAE), offset and slope from linear regression (mean geometric regression) as well as Nash-Sutcliffe coefficient (NS) and $R^{2}$

\begin{tabular}{|c|c|c|c|c|c|c|c|c|c|}
\hline Flux & Land use & EBC & Number of observations & $\operatorname{Bias}\left(\mathrm{W} \mathrm{m}^{-2}\right)$ & $\operatorname{MAE}\left(\mathrm{W} \mathrm{m}^{-2}\right)$ & Offset $\left(\mathrm{W} \mathrm{m}^{-2}\right)$ & Slope $(-)$ & NS (-) & $R^{2}(-)$ \\
\hline \multirow[t]{5}{*}{$Q_{\mathrm{H}}$} & \multirow[t]{2}{*}{ Grass $^{-}$} & Bo & 627 & 52.2 & 55.5 & 36.8 & 1.13 & 0.26 & 0.80 \\
\hline & & HB & 572 & 38.3 & 55.5 & 36.9 & 1.01 & 0.36 & 0.62 \\
\hline & \multirow[t]{2}{*}{ Grass $^{+}$} & Bo & 81 & 18.5 & 23.8 & 17.2 & 1.02 & 0.61 & 0.78 \\
\hline & & HB & 71 & -24.4 & 40.5 & 12.9 & 0.7 & 0.38 & 0.52 \\
\hline & Lake & - & 327 & -2.7 & 7.6 & 5.3 & 0.72 & 0.75 & 0.79 \\
\hline \multirow[t]{5}{*}{$Q_{\mathrm{E}}$} & \multirow[t]{2}{*}{ Grass $^{-}$} & Bo & 627 & -10.8 & 45.3 & -8.6 & 0.99 & 0.70 & 0.73 \\
\hline & & $\mathrm{HB}$ & 572 & -0.4 & 42.0 & -14.3 & 1.1 & 0.68 & 0.74 \\
\hline & \multirow[t]{2}{*}{ Grass $^{+}$} & Bo & 81 & -28.6 & 50.8 & 13.5 & 0.77 & 0.60 & 0.69 \\
\hline & & HB & 71 & 1.7 & 23.4 & 5.4 & 0.98 & 0.82 & 0.82 \\
\hline & Lake & - & 392 & -23.3 & 30.3 & -8.5 & 0.9 & 0.50 & 0.64 \\
\hline
\end{tabular}

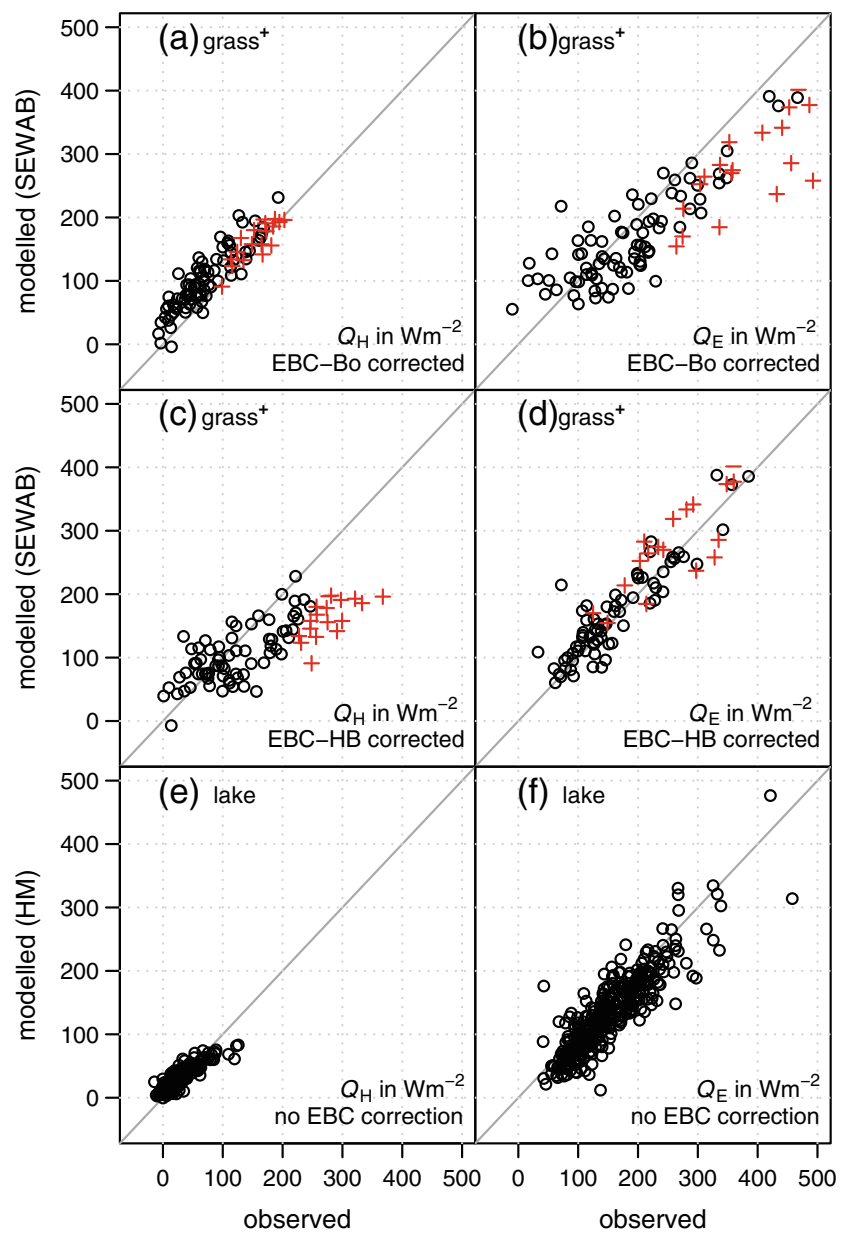

Fig. 6 Scatterplots of modelled and observed turbulent fluxes. For land surface flux observations (grass ${ }^{+}$) vs. SEWAB model simulations, observations are energy balance corrected with the Bowen ratio method (a, b) and with the buoyancy method (c, d). Turbulent fluxes without EBC correction over lake vs. HM model runs (e, f). Model performance is indicated with the Nash-Sutcliffe coefficient, bias and the squared Pearson correlation coefficient. Red crosses indicated data excluded because of residuals - Res $>150 \mathrm{Wm}^{-2}$ the remaining bias can be attributed to uncertainties in estimation of the observed ground heat flux due to high gravel content in the soil and a lack of temperature measurements in the topmost soil layer.

\subsection{Footprint and spatial integration}

In the previous section, we have shown that eddy-covariance measurements, selected according to their footprint as pure fluxes from each surface type, can be represented by SEWAB in case of grassland and by the HM model in case of the lake surface. However, a part of the measurements show contributions from more than one land use type as well. The footprint concept enables us to link the simulations even with such observations. For each time step, the footprint approach provides the relative contribution of all involved surfaces to the measured fluxes. The simulations are then related to the observations by calculating a weighted mean from the output of both models according to the actual land use contribution. This is shown with the footprint integrated simulations for lake and grass ${ }^{+}$together with the EC observations at NamUBT in Fig. 7 for three different situations: 17 July-changing conditions under moderate wind velocities, 5 August-typical day with land-lake circulation and moderate winds of about 2-6 ms ${ }^{-1}$ and 6 August-situation with larger than average wind speeds of about $6 \mathrm{~ms}^{-1}$. In all selected situations the eddy-covariance measurements can be closely modelled by the footprint integrated simulation. This also holds for measurements with contributions from both surfaces, seen in some events on 17 July and 5 August. Instantaneous turbulent fluxes can show differences of up to $200 \mathrm{~W} \mathrm{~m}^{-2}$ because of the different exchange of each surface with its atmosphere over the course of the day. The performance of the footprint-integrated simulation is displayed in Fig. 8 for the whole period. Situations with contributions from both surface types larger than $20 \%$ 


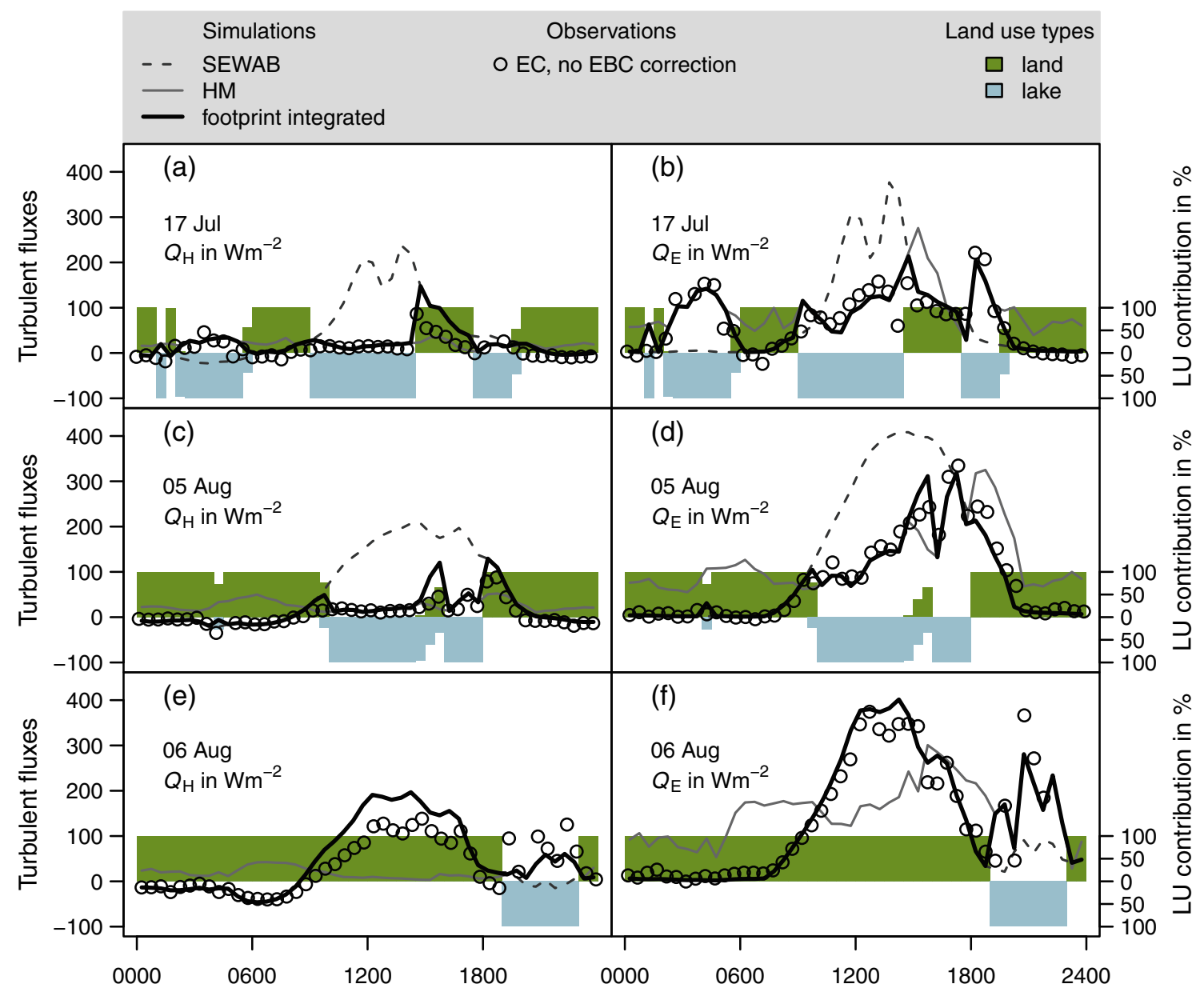

Fig. 7 Source weight integrated modelled fluxes at NamUBT, 17 July (a, b), 5 August (c, d) and 6 August (e, f). Displayed are simulated fluxes with SEWAB (dashed line) and HM (solid grey line) and integrated simulations (solid black line) according to contributions of lake or land within the footprint. Observations (not energy balance corrected) are shown as black circles. The land use contribution in per cent is indicated as bar plot, with upwind situations from the land in green and upwind situations from lake in blue. The time axis is displayed in Beijing standard time (CST); mean local solar noon during the observation period is at $1400 \mathrm{CST}$

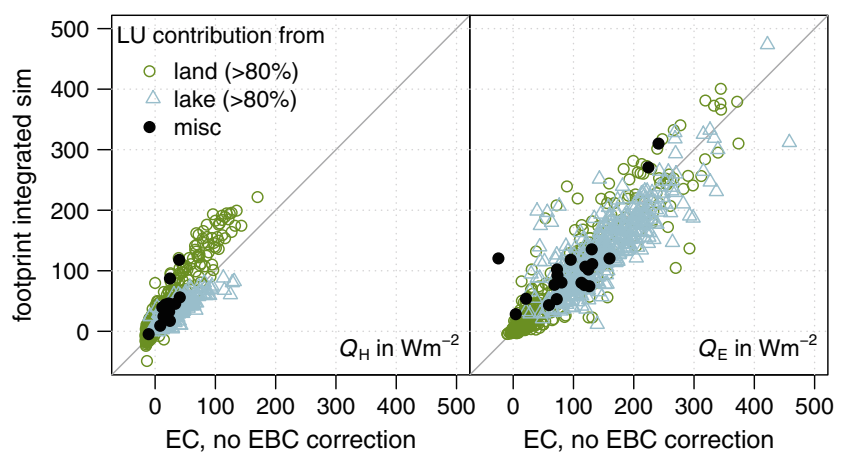

Fig. 8 Observations vs. footprint integrated model simulations at NamUBT. Three classes of data are presented, cases with a greater contribution than $80 \%$ of one land use type are considered as representative. The misc cases contain all fluxes with a contribution less than $80 \%$ for both land use types. Since no EBC correction could be performed for the lake data, all data are shown without correction for better inter comparison (misc) are highlighted. The simulations for such situations follow the same pattern as simulations for the pure surface types (contribution of a single surface greater than $80 \%$ ). Miscellaneous footprints, however, did not occur for situations with very high fluxes.

\subsection{Flux heterogeneity at Nam Co}

It is well known that heterogeneous surfaces affect the landscape scale fluxes. The presented measurements have shown that the fluxes over land and lake surfaces behave differently. To consider the most abundant surfaces near Nam Co station, grass ${ }^{-}$at NamITP has also been included in addition to the observations and simulations of grass ${ }^{+}$and lake at NamUBT. Figure 9 shows the mean diurnal cycles of measured fluxes, corrected with EBC-Bo for land surfaces, and modelled fluxes. The model simulations resemble the observed characteristics of the different surfaces in a reasonable sense. 
Fig. 9 Mean diurnal cycles for the whole measurement period. Observed fluxes (corrected with EBC-Bo) are denoted by black solid lines, the horizontal bars indicate the respective standard deviation; grey lines show the modelled fluxes with standard deviations given by the grey shaded area. The time axis is displayed in Beijing standard time (CST); mean local solar noon during the observation period is at $1400 \mathrm{CST}$

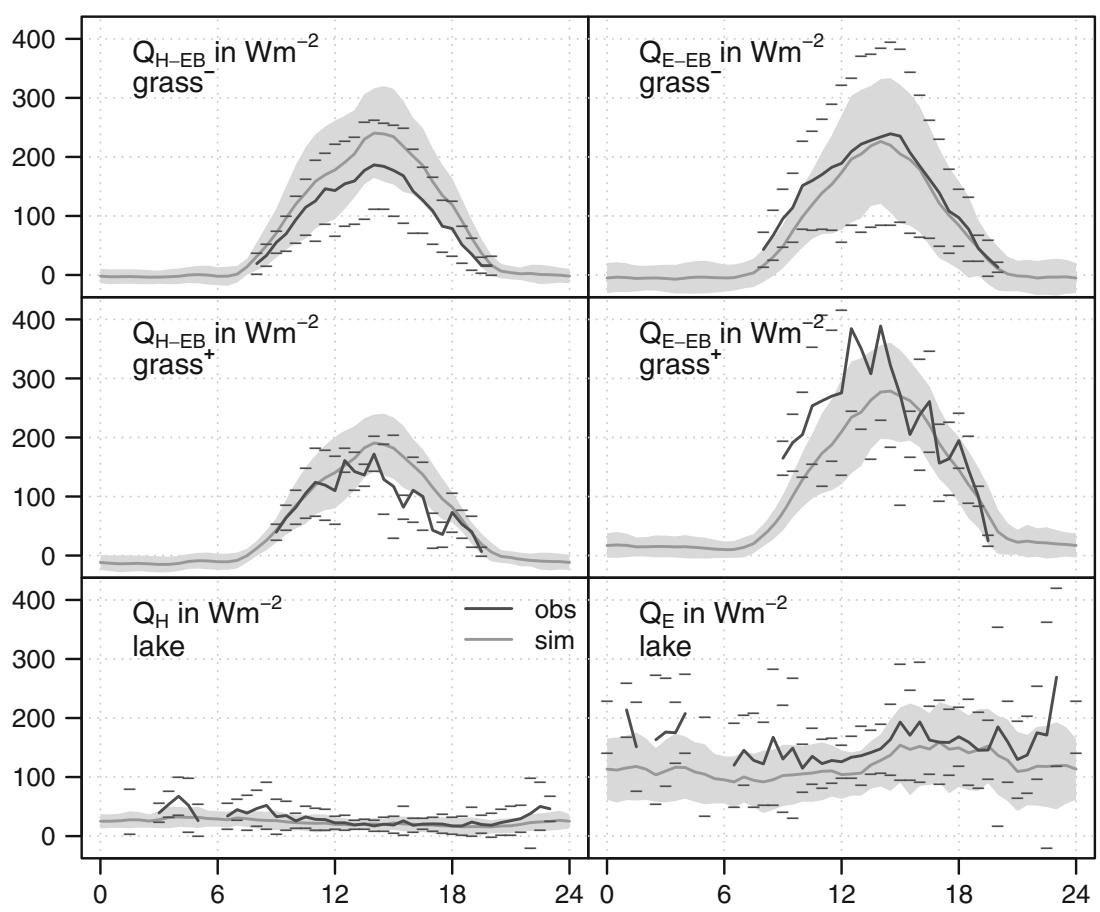

Since simulations overestimated the sensible heat flux for both land surfaces, the differences between land use types were maintained.

The obvious differences in characteristics of the investigated surfaces, especially between land and lake, are also reflected in mean fluxes for the whole period (Fig. 10). The two land surface types already differ in the longwave radiation balance. As expected, the mean latent heat flux became

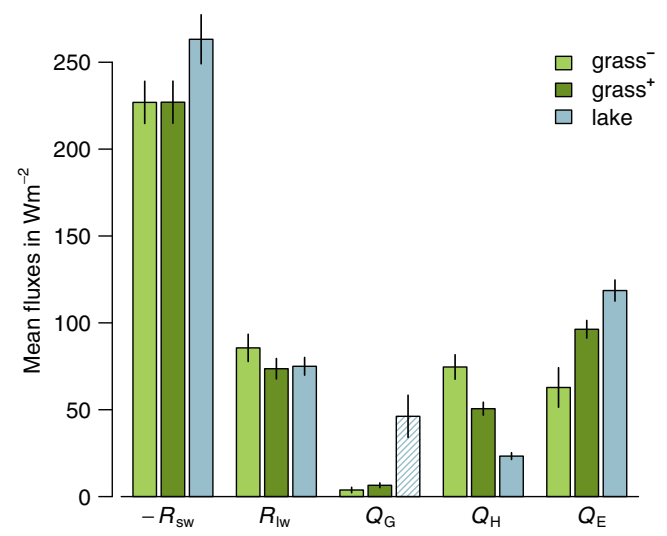

Fig. 10 Mean fluxes for the three surface types grass $^{-}$, grass $^{+}$and lake) from observation-based simulations. Land surfaces fluxes are SEWAB output. Net shortwave radiation $\left(R_{S w}\right)$ and net longwave radiation $\left(R_{l w}\right)$ for the lake surface are calculated as explained in Fig. 5. The residual of the lake energy balance is shown as hatched bar $\left(Q_{g}\right)$; it sums up the energy fluxes not accounted for, e.g. storage change in the water body and flux into the sediment. For land surface fluxes, $Q_{\mathrm{g}}$ represents the ground heat flux. Error bars indicate 1.96 times the standard error of the mean, based on daily mean fluxes; assuming normal distribution and statistical independence of daily mean fluxes, the bars would correspond to the $95 \%$ confidence interval more dominant with increasing soil moisture for the land surfaces. The evaporation over the small lake is even higher, due to its shallow water table resulting in comparatively high surface temperatures. Mean differences of sensible and latent heat flux between grass ${ }^{+}$and grass ${ }^{-}$are 24.0 and $-33.5 \mathrm{~W} \mathrm{~m}^{-2}$, respectively, and between grass ${ }^{+}$and lake are -27.3 and $22.3 \mathrm{~W} \mathrm{~m}^{-2}$, respectively.

Furthermore, we investigated whether these mean differences were substantial with respect to the performance of the simulation. Table 5 displays the mean absolute differences $\delta_{\text {sim }}$ between grass ${ }^{+}$and the other two surface types. As $\delta_{\text {sim }}$ is calculated for the data subset used to evaluate the model performance at grass $^{+}$( $n=81$ for EBC-Bo and $n=71$ for EBC-HB), it can be compared directly to the respective MAE for grass ${ }^{+}$. When comparing the sensible heat flux of the two land surfaces, mean differences between simulations slightly exceed the respective MAE, and it is substantially higher in the other cases, especially between the lake surface and grass ${ }^{+}$. Obviously, this also holds true when comparing grass $^{-}$with lake (not shown). This suggests that the differences in fluxes between land use types exceed the uncertainty with respect to model simulation.

\section{Conclusions}

Turbulent fluxes over wet grassland and a shallow lake were measured with a single eddy-covariance complex at a shallow lake in the Nam Co basin during the monsoon season in 2009. The measurements were split up according to the underlying surface by footprint analysis, and the coordinate 
Table 5 Mean absolute differences $\left(\delta_{\text {sim }}\right)$ between simulations of grass $^{+}$and the other two land use types: grass ${ }^{-}$and lake

\begin{tabular}{lll}
\hline & $Q_{\mathrm{H}}$ & $Q_{\mathrm{E}}$ \\
\hline Grass $^{+}-$grass $^{-}$ & $43.3(81)$ & $59.5(81)$ \\
& $45.9(71)$ & $59.1(71)$ \\
Grass $^{+}$-lake & $76.1(81)$ & $68.1(81)$ \\
& $83.5(71)$ & $57.8(71)$ \\
\hline
\end{tabular}

Numbers in parentheses are the number of data points used, corresponding to the number of observations used to calculate the MAE for grass ${ }^{+}$ in Table 4

rotation for this non-flat terrain has been successfully performed with a sector-wise application of the planar-fit method. Energy balance closure algorithms were deployed, and gap-free time series were derived by surface modelling. We showed that the modelled time series can be linked to the measurements by integration according to the contribution of each surface type. Finally, this data set was compared with observed and modelled fluxes from the nearby ITP station with a target land use of dry grassland. Sharp differences in characteristics of turbulent fluxes from the three dominant land use types found in close vicinity to the lake were revealed.

Both models we used, HM and SEWAB, are able to reproduce the characteristics, magnitude and dynamics reasonably well without deploying optimisation algorithms. There are no parameters which need to be tuned for the HM model except the lake depth. The sensitivity and error analysis for the HM model suggests that expected errors do not exceed the measurement uncertainty of eddy-covariance fluxes. The model parameters for SEWAB have been constrained by measurements. However, a bias remains, in particular at the grass ${ }^{-}$site. This depends not only on model deficiencies, but on the method applied for the energy balance closure correction as well. As long as the underlying mechanism causing the gap is not specified clearly (Foken et al. 2011), this error cannot be exactly determined. On the other hand, measurements of available energy are prone to errors as well, especially in the estimation of the ground heat flux. Nonetheless, it was shown that the differences among land use types of dry grassland, wet grassland and lake exceed the simulation errors. We therefore assume that the simulated time series are able to resolve the differences between the land use types involved here.

The footprint (source weight) integrated modelled fluxes resemble the observations at NamUBT reasonably well, even for conditions where both lake and grass ${ }^{+}$contribute to the measured flux. With the tile approach, a grid cell with edge lengths of $1-5 \mathrm{~km}$ can be directly linked to the simulation as long as the relative contribution of each land use type is known for this cell. Our finding shows that the tile approach is valid in this terrain for spatial integration. Therefore, representative flux simulations can be given for each time step for comparison with remote sensing data.
The measurements over dry grassland at NAMORS are considered to be a reference for the land surface exchange in the Nam Co region. However, in regional estimates the pronounced differences in the fluxes from the three investigated surface types make it obvious that the fluxes above the lake and moist grassland should be taken into account as well. Daytime turbulent fluxes over the lake surface can differ from the land surface fluxes up to $200 \mathrm{~W} \mathrm{~m}^{-2}$. Therefore the land use distribution within a remote sensing pixel or grid cell for mesoscale modelling has to be carefully determined before validating with the dry grassland station. This potential representation error can be reduced by integrating the simulated fluxes of adjacent land use types according to their contribution to the respective grid cell.

The conducting of eddy covariance measurements over lake surfaces on the Tibetan Plateau poses a rarely met challenge. Nevertheless, more accurate flux estimates will be necessary since a significant fraction of the Tibetan Plateau is covered with lakes of various sizes and therefore different characteristics. Based on this study, we can conclude that theoretical requirements for eddy covariance are not substantially violated by the topography at the shoreline station and that the data can be accepted for the HM model validation. Unfortunately, data from the lake surface was only available for unstable and neutral stratification. We showed that the HM model can be used to estimate lake evaporation for these conditions at a highquality standard and a temporal resolution, even resolving the diurnal course. This can be derived from standard land-based meteorological measurements, and a representative surface temperature being the only measurement required directly from the lake. Lake surface exchange under stable conditions, however, could not be validated, but the results from Panin et al. (2006b) indicate reasonable performance also for stable conditions. On the other hand, due to the prevailing high wind velocities, strong stable stratification above lake surfaces on the Tibetan Plateau is unlikely. However, temperature profile measurements at different locations in the lake (and sediment, where indicated) would be a costly but valuable addition to estimate necessary storage terms and thereby the observed energy balance closure. Especially for large lakes like the Nam Co, the estimation of water temperature requires more efforts since multiple locations within the lake should be sampled.

Acknowledgements This work was funded by the German Research Foundation (Deutsche Forschungsgemeinschaft (DFG)) Priority Programme 1372 "Tibetan Plateau: Formation, Climate, Ecosystems"(TiP) and CEOP-AEGIS, a Collaborative Project/Small or medium-scale focused research project-Specific International Co-operation Action coordinated by the University of Strasbourg, France and funded by the European Commission under FP7 topic ENV.2007.4.1.4.2 "Improving observing systems for water resource management". The authors would like to thank everybody who participated in the collection of the data on the Tibetan Plateau, especially the colleagues from the ITP for logistical support during the field campaign. Furthermore, the authors acknowledge H.T. Mengelkamp for providing the source code of SEWAB. The publication costs including open access was funded by the German Research Foundation. 
Open Access This article is distributed under the terms of the Creative Commons Attribution License which permits any use, distribution, and reproduction in any medium, provided the original author(s) and the source are credited.

\section{References}

Alapaty K, Pleim JE, Raman S, Niyogi DS, Byun DW (1997) Simulation of atmospheric boundary layer processes using localand nonlocal-closure schemes. J Appl Meteorol 36(3):214-233. doi:10.1175/1520-0450(1997)036<0214:SOABLP $>2.0 . C O ; 2$

Babel W, Chen Y, Biermann T, Yang K, Ma Y, Foken T (2013) Adaptation of a land surface scheme for modeling turbulent fluxes on the Tibetan Plateau under different soil moisture conditions. J Geophys Res (in press)

Beyrich F, Leps J, Mauder M, Bange J, Foken T, Huneke S, Lohse H, Lüdi A, Meijninger WML, Mironov D, Weisensee U, Zittel P (2006) Area-averaged surface fluxes over the LITFASS region based on eddy-covariance measurements. Boundary-Layer Meteorol 121(1):33-65. doi:10.1007/s10546-006-9052-x

Biermann T, Babel W, Olesch J, Foken T (2009) Documentation of the micrometeorological experiment, Nam Tso, Tibet, 25th of June-8th of August 2009. Work Report University of Bayreuth, Dept. of Micrometeorology. ISSN 1614-8916, 41, 38 pp., URL http:// opus.ub.uni-bayreuth.de/opus4-ubbayreuth/frontdoor/index/index/ docId/626

Boos WR, Kuang Z (2010) Dominant control of the South Asian monsoon by orographic insulation versus plateau heating. Nature 463(7278):218-222. doi:10.1038/nature08707

Chen Y, Yang K, Tang W, Qin J, Zhao L (2012) Parameterizing soil organic carbon's impacts on soil porosity and thermal parameters for Eastern Tibet grasslands. Sci China Earth Sci 55:1001-1011. doi:10.1007/s11430-012-4433-0

Clapp RB, Hornberger GM (1978) Empirical equations for some soil hydraulic properties. Water Resour Res 14(4):601-604

Cukier R, Levine H, Shuler K (1978) Nonlinear sensitivity analysis of multi-parameter model systems. J Comput Phys 26(1):1-42. doi:10.1016/0021-9991(78)90097-9

Davidan I, Lopatuhin L, Rogkov V (1985) Volny v okeane (waves in the ocean). Gidrometeoizdat, Leningrad, $256 \mathrm{pp}$

Finnigan J, Clement R, Malhi Y, Leuning R, Cleugh H (2003) A reevaluation of long-term flux measurement techniques, part I: averaging and coordinate rotation. Bound-Lay Meteorol 107:1-48. doi:10.1023/A:1021554900225

Foken T (1979) Vorschlag eines verbesserten Energieaustauschmodells mit Berücksichtigung der molekularen Grenzschicht der Atmosphäre. Z Meteorol 29:32-39

Foken T (1984) The parameterisation of the energy exchange across the air-sea interface. Dynam Atmos Oceans 8(3-4):297-305. doi:10. 1016/0377-0265(84)90014-9

Foken T (1986) An operational model of the energy exchange across the air-sea interface. Z Meteorol 36:354-359

Foken T (2008) The energy balance closure problem: an overview. Ecol Appl 18(6):1351-1367, URL http://www.jstor.org/stable/40062260

Foken T, Skeib G (1983) Profile measurements in the atmospheric nearsurface layer and the use of suitable universal functions for the determination of the turbulent energy exchange. Bound-Lay Meteorol 25:55-62. doi:10.1007/BF00122097

Foken T, Wichura B (1996) Tools for quality assessment of surfacebased flux measurements. Agr Forest Meteorol 78(1-2):83-105

Foken T, Göckede M, Mauder M, Mahrt L, Amiro B, Munger W (2004) Post-field data quality control. In: Lee X, Massman W, Law B (eds) Handbook of micrometeorology. Kluwer, Dordrecht, pp 181-208
Foken T, Mauder M, Liebethal C, Wimmer F, Beyrich F, Leps JP, Raasch S, DeBruin H, Meijninger W, Bange J (2010) Energy balance closure for the LITFASS-2003 experiment. Theor Appl Climatol 101:149-160. doi:10.1007/s00704-009-0216-8

Foken T, Aubinet M, Finnigan JJ, Leclerc MY, Mauder M, Paw UKT (2011) Results of a panel discussion about the energy balance closure correction for trace gases. B Am Meteorol Soc 92(4):ES13-ES18. doi:10.1175/2011BAMS3130.1

Foken T, Leuning R, Oncley SR, Mauder M, Aubinet M (2012) Corrections and data quality control. In: Aubinet M, Vesala T, Papale D (eds) Eddy covariance: a practical guide to measurement and data analysis. Springer, Dordrecht, pp 85-131. doi:10.1007/ 978-94-007-2351-1 4

Frauenfeld OW, Zhang T, Serreze MC (2005) Climate change and variability using European Centre for Medium-Range Weather Forecasts reanalysis (ERA-40) temperatures on the Tibetan Plateau. J Geophys Res 110(D2):D02101. doi:10.1029/2004JD 005230

Gerken T, Babel W, Hoffmann A, Biermann T, Herzog M, Friend AD, Li M, Ma Y, Foken T, Graf HF (2012) Turbulent flux modelling with a simple 2-layer soil model and extrapolated surface temperature applied at Nam Co lake basin on the Tibetan Plateau. Hydrol Earth Syst Sci 16(4):1095-1110. doi:10.5194/hess-16-1095-2012

Göckede M, Rebmann C, Foken T (2004) A combination of quality assessment tools for eddy covariance measurements with footprint modelling for the characterisation of complex sites. Agr Forest Meteorol 127(3-4):175-188. doi:10.1016/j.agrformet.2004.07.012

Göckede M, Foken T, Aubinet M, Aurela M, Banza J, Bernhofer C, Bonnefond JM, Brunet Y, Carrara A, Clement R, Dellwik E, Elbers J, Eugster W, Fuhrer J, Granier A, Grunwald T, Heinesch B, Janssens IA, Knohl A, Koeble R, Laurila T, Longdoz B, Manca G, Marek M, Markkanen T, Mateus J, Matteucci G, Mauder M, Migliavacca M, Minerbi S, Moncrieff J, Montagnani L, Moors E, Ourcival JM, Papale D, Pereira J, Pilegaard K, Pita G, Rambal S, Rebmann C, Rodrigues A, Rotenberg E, Sanz MJ, Sedlak P, Seufert G, Siebicke L, Soussana JF, Valentini R, Vesala T, Verbeeck H, Yakir D (2008) Quality control of carboeurope flux data-part 1: coupling footprint analyses with flux data quality assessment to evaluate sites in forest ecosystems. Biogeosciences 5(2):433-450. doi:10.5194/bg-5-433-2008

Gu S, Tang Y, Cui X, Kato T, Du M, Li Y, Zhao X (2005) Energy exchange between the atmosphere and a meadow ecosystem on the Qinghai-Tibetan Plateau. Agr and Forest Meteorol 129(3-4):175185. doi:10.1016/j.agrformet.2004.12.002

Haginoya S, Fujii H, Kuwagata T, Xu J, Ishigooka Y, Kang S, Zhang Y (2009) Air-lake interaction features found in heat and water exchanges over Nam Co on the Tibetan Plateau. Sola 5:172-175. doi:10.2151/sola.2009-044

Hong J, Kim J (2010) Numerical study of surface energy partitioning on the Tibetan Plateau: comparative analysis of two biosphere models. Biogeosciences 7(2):557-568. doi:10.5194/bg-7-5572010

Hu Z, Yu G, Zhou Y, Sun X, Li Y, Shi P, Wang Y, Song X, Zheng Z, Zhang L, Li S (2009) Partitioning of evapotranspiration and its controls in four grassland ecosystems: application of a two-source model. Agr Forest Meteorol 149(9):1410-1420. doi:10.1016/ j.agrformet.2009.03.014

Huang Z, Xue B, Yao S, Pang Y (2008) Lake evolution and its implication for environmental changes in China during 1950-2000. J Geogr Sci 18(2):131-141. doi:10.1007/s11442-008-0131-4

Immerzeel WW, van Beek LPH, Bierkens MFP (2010) Climate change will affect the Asian water towers. Science 328(5984):1382-1385. doi:10.1126/science. 1183188

Ingwersen J, Steffens K, Högy P, Warrach-Sagi K, Zhunusbayeva D, Poltoradnev M, Gäbler M, Wizemann HD, Fangmeier A, Wulfmeyer V, Streck T (2011) Comparison of Noah simulations 
with eddy covariance and soil water measurements at a winter wheat stand. Agr Forest Meteorol 151(3):345-355. doi:10.1016/ j.agrformet.2010.11.010

Kang S, Xu Y, You Q, Flügel W, Pepin N, Yao T (2010) Review of climate and cryospheric change in the Tibetan Plateau. Environ Res Lett 5(1):15101

Keil A, Berking J, Mügler I, Schütt B, Schwalb A, Steeb P (2010) Hydrological and geomorphological basin and catchment characteristics of Lake Nam Co, South-Central Tibet. Quat Int 218(12):118-130. doi:10.1016/j.quaint.2009.02.022

Kracher D, Mengelkamp HT, Foken T (2009) The residual of the energy balance closure and its influence on the results of three SVAT models. Meteorol Z 18(6):1-15. doi:10.1127/0941-2948/2009/0412

Krause P, Biskop S, Helmschrot J, Flügel W, Kang S, Gao T (2010) Hydrological system analysis and modelling of the Nam Co basin in Tibet. Adv Geosci 27:29-36. doi:10.5194/adgeo-27-29-2010

Liu J, Kang S, Gong T, Lu A (2010) Growth of a high-elevation large inland lake, associated with climate change and permafrost degradation in Tibet. Hydrol Earth Syst Sci 14(3):481-489. doi:10.5194/ hess-14-481-2010

Louis J (1979) A parametric model of vertical eddy fluxes in the atmosphere. Bound-Lay Meteorol 17:187-202. doi:10.1007/ BF00117978

Lüers J, Bareiss J (2010) The effect of misleading surface temperature estimations on the sensible heat fluxes at a high arctic site - the arctic turbulence experiment 2006 on Svalbard (ARCTEX-2006). Atmos Chem Phys 10(1):157-168. doi:10.5194/acp-10-157-2010

Ma W, Ma Y (2006) The annual variations on land surface energy in the northern Tibetan Plateau. Environ Geol 50(5):645-650. doi:10.1007/s00254-006-0238-9

Ma Y, Su Z, Koike T, Yao T, Ishikawa H, Ueno K, Menenti M (2003) On measuring and remote sensing surface energy partitioning over the Tibetan Plateau - from GAME/Tibet to CAMP/Tibet. Appl Quant Remote Sensing Hydrol 28(1-3):63-74. doi:10.1016/ S1474-7065(03)00008-1

Ma Y, Fan S, Ishikawa H, Tsukamoto O, Yao T, Koike T, Zuo H, Hu Z, $\mathrm{Su} Z$ (2005) Diurnal and inter-monthly variation of land surface heat fluxes over the central Tibetan Plateau area. Theor Appl Climatol 80(2-4):259-273. doi:10.1007/s00704-004-0104-1

Ma Y, Wang Y, Wu R, Hu Z, Yang K, Li M (2009) Recent advances on the study of atmosphere-land interaction observations on the Tibetan Plateau. Hydrol Earth Syst Sci 13(7): 1103-1111

Mauder M, Foken T (2004) Documentation and instruction manual of the eddy covariance software package TK2. Work Report University of Bayreuth, Dept. of Micrometeorology, ISSN 1614 8916, 26, 42 pp., URL http://opus.ub.uni-bayreuth.de/opus4ubbayreuth/frontdoor/index/index/docId/639

Mauder M, Foken T (2006) Impact of post-field data processing on eddy covariance flux estimates and energy balance closure. Meteorol Z 15(13):597-609. doi:10.1127/0941-2948/2006/0167

Mauder M, Foken T (2011) Documentation and instruction manual of the eddy-covariance software package TK3. Work Report University of Bayreuth, Dept. of Micrometeorology, ISSN 16148916, 46, 58 pp., URL http://opus.ub.uni-bayreuth.de/opus4ubbayreuth/frontdoor/index/index/docId/681

Mauder M, Foken T, Clement R, Elbers JA, Eugster W, Grünwald T, Heusinkveld B, Kolle O (2008) Quality control of CarboEurope flux data-part 2: inter-comparison of eddy-covariance software. Biogeosciences 5(2):451-462. doi:10.5194/bg-5-451-2008

Maussion F, Scherer D, Finkelnburg R, Richters J, Yang W, Yao T (2011) WRF simulation of a precipitation event over the Tibetan Plateau, China - an assessment using remote sensing and ground observations. Hydrol Earth Syst Sci 15(6):1795-1817. doi:10.5194/ hess-15-1795-2011

Mengelkamp HT, Warrach K, Raschke E (1999) SEWAB - a parameterization of the surface energy and water balance for atmospheric and hydrologic models. Adv Water Resour 23(2):165-175. doi:10.1016/S0309-1708(99)00020-2

Mengelkamp HT, Kiely G, Warrach K (2001) Evaluation of the hydrological components added to an atmospheric land-surface scheme. Theor Appl Climatol 69(3-4):199-212. doi:10.1007/s007040170025

Metzger S, Ma Y, Markkanen T, Göckede M, Li M, Foken T (2006) Quality assessment of Tibetan Plateau eddy covariance measurements utilizing footprint modeling. Adv Earth Sci 21(12):12601267

Mihailović DT, Pielke RA, Rajković B, Lee TJ, Jeftić M (1993) A resistance representation of schemes for evaporation from bare and partly plant-covered surfaces for use in atmospheric models. J Appl Meteorol 32(6):1038-1054. doi:10.1175/1520-0450(1993) 032<1038:ARROSF $>2.0 . \mathrm{CO} ; 2$

Molnar P, Boos WR, Battisti DS (2010) Orographic controls on climate and Paleoclimate of Asia: thermal and mechanical roles for the Tibetan Plateau. Annu Rev Earth Planet Sci 38(1):77-102. doi:10.1146/annurev-earth-040809-152456

Mügler I, Gleixner G, Günther F, Mäusbacher R, Daut G, Schütt B, Berking J, Schwalb A, Schwark L, Xu B, Yao T, Zhu L, Yi C (2010) A multi-proxy approach to reconstruct hydrological changes and Holocene climate development of Nam Co, Central Tibet. J Paleolimnol 43(4):625-648. doi:10.1007/s10933-0099357-0

Ni J (2011) Impacts of climate change on Chinese ecosystems: key vulnerable regions and potential thresholds. Reg Environ Chang 11(1):49-64. doi:10.1007/s10113-010-0170-0

Noilhan J, Planton S (1989) A simple parameterization of land surface processes for meteorological models. Mon Weather Rev 117(3):536549. doi:10.1175/1520-0493(1989)117<0536:ASPOLS >2.0.CO;2

Nordbo A, Launiainen S, Mammarella I, Lepparanta M, Huotari J, Ojala A, Vesala T (2011) Long-term energy flux measurements and energy balance over a small boreal lake using eddy covariance technique. J Geophys Res 116(D2):D02119

Panin GN, Foken T (2005) Air-sea interaction including a shallow and coastal zone. J Atmos Ocean Sci 10(3):289-305. doi:10.1080/ 17417530600787227

Panin GN, Nasonov AE, Foken T (2006a) Evaporation and heat exchange of a body of water with the atmosphere in a shallow zone. Izv Atmos Ocean Phys 42(3):337-352. doi:10.1134/ S0001433806030078

Panin GN, Nasonov AE, Foken T, Lohse H (2006b) On the parameterization of evaporation and sensible heat exchange for shallow lakes. Theor Appl Climatol 85:123-129. doi:10.1007/s00704005-0185-5

Paw UK, Baldocchi D, Meyers T, Wilson K (2000) Correction of eddycovariance measurements incorporating both advective effects and density fluxes. Bound-Lay Meteorol 97:487-511. doi:10.1023/ A: 1002786702909

Rannik U, Aubinet M, Kurbanmuradov O, Sabelfeld KK, Markkanen T, Vesala T (2000) Footprint analysis for measurements over a heterogeneous forest. Bound-Lay Meteorol 97(1):137-166. doi:10.1023/ A:1002702810929

Rebmann C, Kolle O, Heinesch B, Queck R, Ibrom A, Aubinet M (2012) Data Acquisition and Flux Calculations. In: Aubinet M, Vesala T, Papale D (eds) Eddy covariance. Springer, Amsterdam, pp 59-83

Rouse WR, Oswald CJ, Binyamin J, Spence C, Schertzer WM, Blanken PD, Bussières N, Duguay CR (2005) The role of Northern Lakes in a regional energy balance. J Hydrometeor 6(3):291-305. doi:10.1175/JHM421.1

Twine TE, Kustas WP, Norman JM, Cook DR, Houser PR, Meyers TP, Prueger JH, Starks PJ, Wesely ML (2000) Correcting eddy-covariance flux underestimates over a grassland. Agr Forest Meteorol 103(3):279-300. doi:10.1016/S0168-1923(00) 00123-4 
Wendisch M, Foken T (1989) Sensitivity test of a multilayer energy exchange model. Z Meteorol 39:36-39

Wilczak J, Oncley S, Stage S (2001) Sonic anemometer tilt correction algorithms. Bound-Lay Meteorol 99:127-150. doi:10.1023/ A: 1018966204465

Wu Y, Zhu L (2008) The response of lake-glacier variations to climate change in Nam Co Catchment, central Tibetan Plateau, during 1970 2000. J Geogr Sci 18(2):177-189. doi:10.1007/s11442-008-0177-3

Xu J, Haginoya S (2001) An estimation of heat and water balances in the Tibetan Plateau. J Meteorol Soc Jpn 79(1B):485-504. doi:10.2151/jmsj.79.485

Xu J, Yu S, Liu J, Haginoya S, Ishigooka Y, Kuwagata T, Hara M, Yasunari T (2009) The implication of heat and water balance changes in a lake basin on the Tibetan Plateau. Hydrol Res Lett 3:1-5. doi:10.3178/hrl.3.1

Yang K, Koike T, Ye B, Bastidas L (2005) Inverse analysis of the role of soil vertical heterogeneity in controlling surface soil state and energy partition. J Geophys Res 110(D8):D08101. doi:10.1029/ 2004JD005500

Yang K, Chen YY, Qin J (2009) Some practical notes on the land surface modeling in the Tibetan Plateau. Hydrol Earth Syst Sci 13(5):687-701. doi:10.5194/hess-13-687-2009
Yang K, Koike T, Ishikawa H, Kim J, Li X, Liu H, Wang J, Liu S, Ma Y (2008) Turbulent flux transfer over bare-soil surfaces: characteristics and parameterization. J Appl Meteorol Clim 47:276-290. doi:10.1175/2007JAMC1547.1

Yang K, Ye B, Zhou D, Wu B, Foken T, Qin J, Zhou Z (2011) Response of hydrological cycle to recent climate changes in the Tibetan Plateau. Clim Chang 109(3-4):517-534. doi:10.1007/s10584-011-0099-4

Yu S, Liu J, Xu J, Wang H (2011) Evaporation and energy balance estimates over a large inland lake in the Tibet-Himalaya. Environ Earth Sci 64(4):1169-1176. doi:10.1007/s12665-011-0933-Z

Zhao L, Li J, Xu S, Zhou H, Li Y, Gu S, Zhao X (2010) Seasonal variations in carbon dioxide exchange in an alpine wetland meadow on the Qinghai-Tibetan Plateau. Biogeosciences 7(4):12071221. doi:10.5194/bg-7-1207-2010

Zhou D, Eigenmann R, Babel W, Foken T, Ma Y (2011) The study of near-ground free convection conditions at Nam Co station on the Tibetan Plateau. Theor Appl Climatol 105(1-2):217-228. doi:10.1007/s00704-010-0393-5

Zhu L, Xie M, Wu Y (2010) Quantitative analysis of lake area variations and the influence factors from 1971 to 2004 in the Nam Co basin of the Tibetan Plateau. Chin Sci Bull 55(13):1294-1303. doi:10.1007/s11434-010-0015-8 